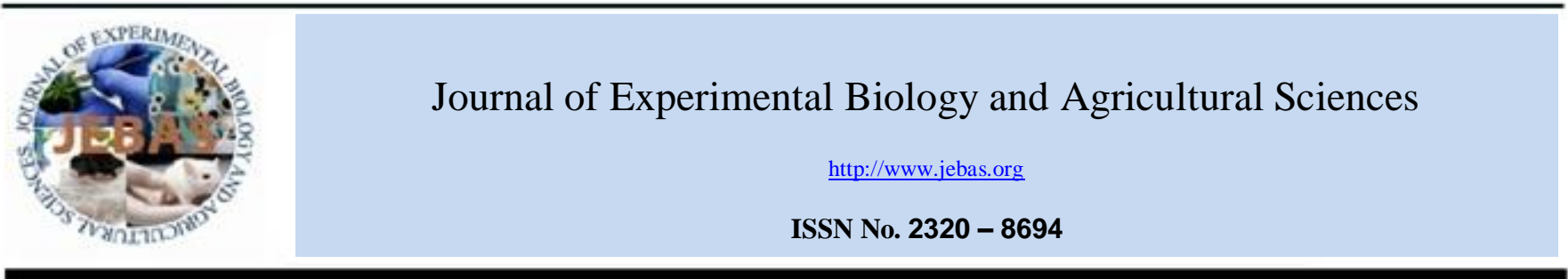

\title{
PRODUCTION OF THE ANTITUMOR L-GLUTAMINASE ENZYME FROM THERMOTOLERANT Streptomyces sp. D214, UNDER SUBMERGED FERMENTATION CONDITIONS
}

\author{
Magda M Aly ${ }^{1 *}$, Roqayah H Kadi ${ }^{2}$, Alia M Aldahlawi ${ }^{1,5}$, Mayson H Alkhatib ${ }^{3}$, \\ Abdulwahab Noor Wali ${ }^{4,6}$
}

\footnotetext{
${ }^{1}$ Biology Department, Faculty of Science, King Abdulaziz University, Jeddah, Saudi Arabia

${ }^{2}$ Biology Department, Faculty of Science, University of Jeddah, Jeddah, Saudi Arabia

${ }^{3}$ Biochemistry Department, Faculty of Science, King Abdulaziz University

${ }^{4}$ Department of Clinical Biochemistry Faculty of Medicine, King Abdulaziz University

${ }^{5}$ Immunology Unit KFMRC, Jeddah, Saudi Arabia

${ }^{6}$ Stem Cell Unit, KFMRC, Jeddah, Saudi Arabia
}

Received - October 20, 2017; Revision - November 11, 2017; Accepted - December 13, 2017

Available Online - December 27, 2017

DOI: http://dx.doi.org/10.18006/2017.5(6).878.885

KEYWORDS
L-glutaminase
Streptomyces
Temperature
$\mathrm{pH}$
Enzyme

\begin{abstract}
L-glutaminase is an amidohydrolase which produced by a variety of microorganisms including bacteria, yeast and fungi. In recent years, it widely used as an anticancer drug and as flavor enhancing agent. This study was aimed to production of extracellular L-glutaminase from bacteria. About 20 soil samples were collected and out of 40 pure bacterial cultures, the isolate RK9 was the most active in L-glutaminase production in solid and broth media containing L- glutamine as the carbon and nitrogen sources. Lglutaminase producing isolate was identified as Streptomyces sp. D214 by using morphological, physiological and molecular characters. Further, it was reported that maximum enzyme production occurred by using minimal medium containing L-glutamine at $\mathrm{pH} 7$ and incubation temperature $45^{\circ} \mathrm{C}$ after 5 days of growth at $120 \mathrm{rpm}$. Addition of $3 \% \mathrm{NaCl}$ enhanced enzyme production. The enzyme was collected and purified by using column chromatography. The purified enzyme showed excellent antitumor activity against the tumor cell line $\mathrm{MCF}-7$ with $\mathrm{IC}_{50}$ of $10 \mu \mathrm{g} / \mathrm{ml}$. In conclusion, saline soil is a good source of bacteria especially genus Streptomyces that produce salt tolerant L-glutaminase, the antitumor agent with more activity and less toxicity.
\end{abstract}

* Corresponding author

E-mail: magdammali@ hotmail.com (Magda M Aly)

Peer review under responsibility of Journal of Experimental Biology and Agricultural Sciences.

Production and Hosting by Horizon Publisher India [HPI] (http://www.horizonpublisherindia.in/).

All rights reserved.
All the article published by Journal of Experimental Biology and Agricultural Sciences is licensed under a Creative Commons Attribution-NonCommercial 4.0 International License Based on a work at www.jebas.org.

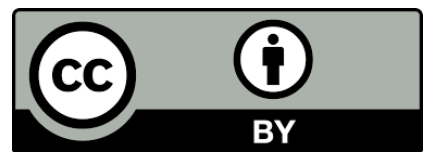




\section{Introduction}

The hydrolytic enzyme L-glutaminase (L-glutamine amidohydrolase, E.C 3.5.1.2) catalyzes the deamination of Lglutamine to glutamic acid and ammonia (Imada et al., 1973). Lglutaminase has received significant attention with respect to its extensive applications in pharmaceuticals as an anti-leukemic agent (Nandakumar et al., 2003) and in food industry as a flavor enhancer (Nakadai \& Nasuno, 1989). Another great application of L-glutaminase is in biosensors for monitoring glutamine levels in mammalian (Balagurunathan et al., 2010). L-glutaminase is widely distributed in microorganism like bacteria, yeast and fungi (Nandakumar et al., 2003). L-glutaminase productions have been reported from E. coli (Prabhu \& Chandrasekaran, 1997), Bacillus subtilis (Dubey et al., 2015)' Proteus morganni, P. vulgaris, Xanthmonas juglandis, Erwnia carotovora, E. aroideae, Serratia marcescens, Enterobacter coacae, Klebsiella aerogenes and Aerobacter aerogenes (Wade et al., 1971). Also, L-glutaminase synthesis has been reported from Streptomyces rimosus (Keerthi et al., 1999), Streptomyces sp.-SBU1 (Krishnakumar et al., 2011) and Streptomyces avermitilis (Abdallah et al., 2013).

Recently, production of industrial enzymes on large scale is a promising technology for the development of several bioprocesses in order to develop comprehensive process monitoring concepts by involving the most significant process variables. The search for enzymes from microbial sources is become urgent need to over produce the enzyme with new and novel characters (Prabhu \& Chandrasekaran, 1997). While commercial production of glutaminase is carried out using submerged fermentation technique, using natural substrates or agricultural residues has also gained much interest due to its various advantages. Actinomycetes are well known to produce a variety of enzymes (Okami, 1986). This study was aimed to produce extracellular Lglutaminase enzyme from thermostable actinomycetes under submerged fermentation and optimize the conditions for maximum enzyme production.

\section{Materials and Methods}

\subsection{Sample collection and bacterial isolation}

Ten (10) saline soil samples were collected from both Red Sea Cost of Jeddah city and ten (10) cultivated soil samples from Taif city, Western region, Saudi Arabia. All the collected samples were taken to the laboratory in sterile plastic bags. One gram of each soil sample was suspended in $9.0 \mathrm{ml}$ of sterile distilled water and $0.1 \mathrm{ml}$ of this suspension was spread on each Petri dish plate containing starch nitrate medium and all these plates were incubated at $45^{\circ} \mathrm{C}$ for 5 days. The colonies which showed powdery growth were selected and transferred to the same medium until pure cultures were obtained. All the obtained isolates were preserved at $4^{\circ} \mathrm{C}$ on slope slant agars. For long preservation (more than six months), strains were kept in $20 \%$ glycerol and stored at $-80^{\circ} \mathrm{C}$ for further study.

\subsection{Screening and selection of L-glutaminase producing isolates}

The strains were preliminary tested for L-glutaminase production using rapid screening method. All isolates were streaked on minimal glutamine agar medium (MGA) plates containing $(\mathrm{g} / \mathrm{l})$ : $\mathrm{KCl}(0.5), \mathrm{MgSO}_{4} .7 \mathrm{H}_{2} \mathrm{O}(0.5), \mathrm{KH}_{2} \mathrm{PO}_{4},(1.0), \mathrm{FeSO}_{4} .7 \mathrm{H}_{2} \mathrm{O}(0.1)$, $\mathrm{ZnSO}_{4} .7 \mathrm{H}_{2} \mathrm{O}$ (1.0) and glutamine (5.0) as the sole carbon and nitrogen source and phenol red (0.012) as a pH indicator. Incubation was carried out at $45^{\circ} \mathrm{C}$ for 5 days and appearance of pink zones around the bacterial growth, indicated a glutaminase production (Balagurunathan \& Subramanian, 1993; Balagurunathan et al., 2010).

Secondary screening for L-glutaminase production in liquid medium was carried out by inoculating the strains that showed positive result in the rapid screening, in modified medium containing (g/l): L-glutamine (20), yeast extract (0.5), $\mathrm{K}_{2} \mathrm{HPO}_{4}$ (1.0), $\mathrm{KH}_{2} \mathrm{PO}_{4}(1.0), \mathrm{MgSO}_{4} .7 \mathrm{H}_{2} \mathrm{O},(0.1), \mathrm{NaCl}$ (1.0) (Wakayama et al., 2005). The medium was prepared $(50 \mathrm{ml})$ in $250 \mathrm{ml}$ Erlemayer flask, sterilized and inoculated with $2 \mathrm{ml}$ of the preculture $\left(4 \times 10^{6} \mathrm{cfu} / \mathrm{ml}\right)$ and incubated at $45^{\circ} \mathrm{C}$ for 5 days. After incubation, the cells were collected by centrifugation at 10.000 rpm for $10 \mathrm{~min}$ at $4^{\circ} \mathrm{C}$ and the clear supernatant was used as crude enzyme (Dura et al., 2002). Then, L-glutaminase production was determined.

\subsection{Identification of the bacterial isolate}

The bacterial isolate that showing the highest L-glutaminase production was identified by using morphological, physiological, biochemical and molecular studies. Spore shape and morphology were determined using light and Scanning electron microscope (JSM 7600F Field Emission Gun Ultra-High Resolution) after growing on starch nitrate agar for 10 days at $45^{\circ} \mathrm{C}$. Classical methods for classification, which were described in the identification key by Nonomura (1974) and Bergey's Manual of Determinative Bacteriology (William et al., 1989) were used.

Bacterial identification was confirmed using molecular characterization techniques also. The bacterial cells were collected and DNA was extracted (Kumar et al., 2010). PCR amplification of the 16S rDNA of the tested bacterium was performed using two primers: 9F (5'-GAGTTTGATCCTGGCTCAG- 3') and 1541R (5' AAGGAGGTGATCCAACC- 3') as recommended by Hall et al. (1999). The DNA sequence was compared to the GenBank database. 


\subsection{Growth and preculture}

The selected isolate was cultured in $250 \mathrm{ml}$ Erlenmeyer flasks containing $50 \mathrm{ml}$ of the starch nitrate medium, at $45^{\circ} \mathrm{C}$ for 4 days at $120 \mathrm{rpm}$. The preculture, $2 \mathrm{ml}$ containing $4 \times 10^{6} \mathrm{cfu} / \mathrm{ml}$, was used to inoculate in each $50 \mathrm{ml}$ of the production medium. At the end of the growth period, growth $\left(\mathrm{A}_{550 \mathrm{~nm}}\right)$ and enzyme activity $(\mathrm{U} / \mathrm{ml})$ were determined.

\subsection{Optimization of culture condition for L-glutaminase production}

The selected isolate was growing $250 \mathrm{ml}$ Erlenmeyer flasks, containing $50 \mathrm{ml}$ of different broth media and L-glutaminase production was determined after 5 days of growth at $45^{\circ} \mathrm{C}$. The used broth media were Medium 1: L-glutaminase, Czapek's medium (Reda, 2015), Medium 2: Mineral Salts Glutamine medium (Renu \& Chandrasekaran, 1992), Medium 3: Minimal glutamine medium (Wakayama et al., 2005), Medium 4 (Sato et al., 1999), Medium 5 (Kumar \& Chandrasekaran, 2003) and Medium 6 (Abdallah et al., 2013). Effect of different incubation temperatures viz. 20, 28, 30, 37, 40, 45, 50 and $55^{\circ} \mathrm{C}$, was determined in minimal glutamine medium under shaking (120 rpm) conditions. Moreover, the selected medium was prepared at different $\mathrm{pH}$ values viz., 6.0, 6.5, 7.0, 7.5, 8.0, 8.5, 9.0 and 9.5, with different carbon (glucose, fructose, maltose, sucrose, starch and glutamine) and nitrogen source (yeast extract, meat extract, potassium nitrate, sodium nitrate and ammonium chloride) along with different concentrations of $\mathrm{NaCl}(0.0,1,2,3,4,5,6 \%)$. After 5 days of growth at $120 \mathrm{rpm}$, the enzyme assay was carried out in the cell free filtrate. The effect of different incubation periods viz., 2, 3, 4, 5 and 6 days on L-glutaminase production was also determined.

At the end of growth period, cells were collected by centrifugation at $10.000 \mathrm{rpm}$ for $10 \mathrm{~min}$ at $4{ }^{\circ} \mathrm{C}$ and the clear supernatant was used to measure L-glutaminase production. The enzyme activity was assayed in triplicate and average values were recorded for each treatment.

\subsection{L-glutaminase assay}

L-glutaminase was assayed according to the method described by Imada et al. (1973). An aliquot of $0.5 \mathrm{ml}$ of the sample was mixed with $0.5 \mathrm{ml}$ of $0.04 \mathrm{ML}$-glutamine solution in the presence of 0.5 $\mathrm{ml}$ of distilled water and $0.5 \mathrm{ml}$ of phosphate buffer $(0.1 \mathrm{M}, \mathrm{pH}$ 8). The mixture was incubated at $37^{\circ} \mathrm{C}$ for $30 \mathrm{~min}$ and the reaction was arrested by the addition of $0.5 \mathrm{ml}$ of $1.5 \mathrm{M}$ trichloroacetic acid. From this mixture, $0.1 \mathrm{ml}$ of the mixture was taken out and mixed with $3.7 \mathrm{ml}$ of distilled water and $0.2 \mathrm{ml}$ of Nessler's reagent and $\mathrm{A}_{450 \mathrm{~nm}}$ was detected. Activity of the enzyme was determined in Unit/ml $(\mathrm{U} / \mathrm{ml})$ and L-glutaminase unit is the amount of the enzyme that liberates one $\mu \mathrm{Mol}$ of ammonia.

\subsection{Enzyme purification and antitumor activity}

Purification was carried out after precipitation using $80 \%$ ammonium sulfate and gel filtration using column chromatography. The active fractions were collected, lyophilized and used for determination of the antitumor activity. The effect of L-glutaminase on cell viability of MCF-7 human breast carcinoma cell line, grown at $37^{\circ} \mathrm{C}$ in a $5 \% \mathrm{CO}_{2}, 95 \%$ air humidified atmosphere, in DMEM supplemented with $10 \%$ heat inactivated Fetal Bovine Serum with penicillin (100 U/ml), streptomycin (100 $\mu \mathrm{g} / \mathrm{ml})$ and Amphotericin B $(5 \mu \mathrm{g} / \mathrm{ml})$ was determined using a colorimetric test, MTT assay. The percentage of growth inhibition was calculated and the concentration of enzyme that inhibits cell growth by $50 \%$ was determined.

\section{Results}

\subsection{Screening of L-glutaminase producing isolates}

Forty bacterial isolates have been obtained after streaking and sub-culturing on starch nitrate medium until pure cultures were obtained. All these isolates were preliminary screened on minimal glutamine agar medium for L-glutaminase production using phenol red as indicator. The results obtained from the preliminary screening revealed that ten bacterial isolates showed color change on minimal glutamine agar medium by formation of pink zones around the microbial growth (Table 1). This establish the fact that all these isolates have ability to utilize L-glutamine and produce

Table 1 Color and L-glutaminase activity of the ten active bacterial isolates

\begin{tabular}{|clcc|}
$\begin{array}{c}\text { Bacterial } \\
\text { isolate }\end{array}$ & Color & $\begin{array}{c}\text { L-glutaminase } \\
\text { detection } \\
\text { ( pink zone, mm) }\end{array}$ & $\begin{array}{c}\text { Activity of } \\
\text { L-glutaminase } \\
(\mathrm{U} / \mathrm{ml})\end{array}$ \\
\hline RK4 & Dark gray & 20 & 8.43 \\
\hline RK6 & Dark gray & 15 & 8.18 \\
\hline RK 9 & Blue & 33 & 10.24 \\
\hline RK14 & Dark gray & 25 & 6.75 \\
\hline RK19 & Blue & 24 & 10.1 \\
\hline RK20 & $\begin{array}{l}\text { Yellowish } \\
\text { brown }\end{array}$ & 26 & 5.2 \\
\hline RK24 & White & 20 & 7.22 \\
\hline RK30 & Dark gray & 20 & 9.1 \\
\hline RK34 & White & 15 & 6.18 \\
\hline RK37 & Dark gray & 22 & \\
\hline
\end{tabular}


L-glutaminase enzyme. The isolate RK9 which was isolated from Red Sea Cost, showed maximum L-glutaminase production, therefore it was selected for rest of the study.

3.2. Morphological, physiological and molecular characterization

The bacterial isolate RK9 grew well on starch nitrate agar and the aerial and substrate mycelia were well developed. The aerial mycelium was pale blue while the substrate mycelium was dark yellow and the reverse color pigment was pale yellow. The spores have a cylindrical shape with smooth surface and the diameter was $1.0 \mu \mathrm{m}$ length and $0.5 \mu \mathrm{m}$ width (Figure 1). Using morphological and physiological characters, the isolate RK9 was identified as spices of the genus Streptomyces and was identified as Streptomyces sp. Identification was confirmed using 16SrDNA and the isolate was identified as Streptomyces sp. D214.

\subsection{Effect of various parameters on L-glutaminase production by Streptomyces sp. D2014}

The effect of different parameters on L-glutaminase production was investigated. It was clear that Streptomyces sp. D2014 showed the maximum L-glutaminase production on Medium 3 (Table 2 and Figure 2), containing glutamine and ammonium chloride as carbon and nitrogen sources, respectively
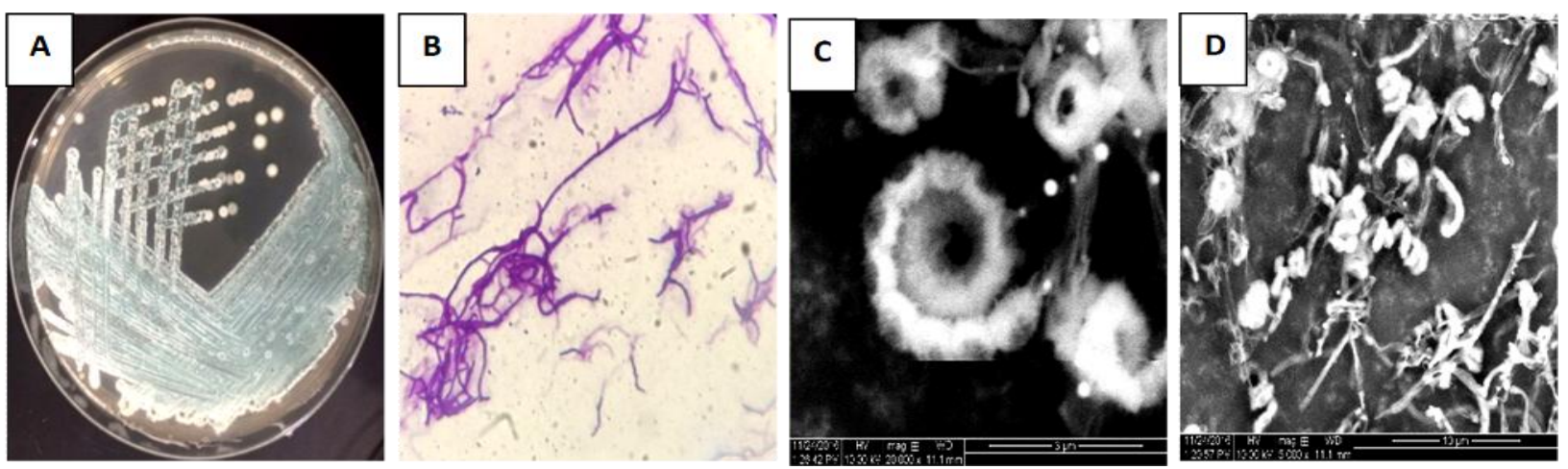

Figure 1 The selected isolate RK9 on Starch nitrate agar (A), under light microscope (B) and scanning electron microscope (C and D)

Table 2 Effect of different media on L-glutaminase production produced by the selected isolate RK9

\begin{tabular}{|c|c|c|c|}
\hline Medium No. & The Medium Used & Composition of medium & $\begin{array}{l}\text { Activity of } \\
\text { L-glutaminase } \\
\quad(\mathrm{U} / \mathrm{ml})\end{array}$ \\
\hline Medium 1 & Reda (2015) & $\begin{array}{l}\text { Modified Czapek's medium contained }(\mathrm{g} / \mathrm{l}): \text { L-glutamine } 10 ; \mathrm{D} \text { - } \\
\text { glucose } 5 ; \mathrm{MgSO}_{4} 7 \mathrm{H}_{2} \mathrm{O} 0.5 ; \mathrm{KCl} 0.05 ; \mathrm{KH}_{2} \mathrm{PO}_{4} 1.0 .\end{array}$ & 12.17 \\
\hline Medium 2 & $\begin{array}{l}\text { Mineral Salts Glutamine } \\
\text { medium } \\
\text { Renu \& Chandrasekaran, } \\
\text { (1992) }\end{array}$ & $\begin{array}{l}\text { L-glutamine } 1 \%, \text { D-Glucose } 0.5 \%, \mathrm{NaCl} 3 \%, \mathrm{KH}_{2} \mathrm{PO}_{4} \quad 0.1 \% \text {, } \\
\mathrm{MgSO}_{4} .7 \mathrm{H}_{2} \mathrm{O} 0.05 \%, \mathrm{CaCl}_{2} 0.01 \%, \mathrm{NaNO}_{3} 0.01 \% \text {, trisodium citrate } \\
0.01 \% \text { and Distilled water } 100 \mathrm{ml}, \mathrm{pH} 6\end{array}$ & 10.89 \\
\hline Medium 3 & $\begin{array}{l}\text { Wakayama et al. } \\
\qquad(2005)\end{array}$ & $\begin{array}{ll}\text { L-Glutamine } & 2.0 \%, \mathrm{~K}_{2} \mathrm{HPO}_{4} \quad 0.1 \%, \mathrm{KH}_{2} \mathrm{PO}_{4} \quad 0.1 \%, \mathrm{MgSO}_{4} 7 \mathrm{H}_{2} \mathrm{O} \\
0.01 \%, \mathrm{NaCl} & 0.1 \% \text { and Yeast extract } 0.05 \% \text {, Distilled water } 100 \mathrm{ml} \\
\text { and pH } 6.0\end{array}$ & 18.032 \\
\hline Medium 4 & Sato et al. (1999) & $\begin{array}{l}\text { D-Glucose } 3.0 \% \text {, yeast extract } 0.5 \%, \mathrm{MgSO}_{4}-0.1 \% \text { and } \mathrm{KH}_{2} \mathrm{PO}_{4} \\
0.1 \% \text {, Distilled water } 100 \mathrm{ml} \text { and } \mathrm{pH} 6.0\end{array}$ & 2.77 \\
\hline Medium 5 & $\begin{array}{l}\text { Kumar \& Chandrasekaran } \\
\text { (2003) }\end{array}$ & $\begin{array}{l}\text { L-Glutamine }-1 \% \text {, D-glucose- } 0.05 \% \text {, Distilled water- } 100 \mathrm{ml} \text { and } \mathrm{pH} \\
6.0\end{array}$ & 13.028 \\
\hline Medium 6 & Abdallah1 et al (2013) & $\begin{array}{l}\text { Mineral salt glutamine (MSG) medium }(\mathrm{pH} 7) \text { include }(\mathrm{g} / \mathrm{l}) 10 \mathrm{~L}- \\
\text { glutamine; } 1.0 \mathrm{KH}_{2} \mathrm{PO}_{4} ; 0.5 \mathrm{MgSO}_{4} ; 0.1 \mathrm{CaCl}_{2} ; 0.1 \mathrm{NaNO}_{3} ; 0.1 \\
\mathrm{Na}_{3} \mathrm{C}_{6} \mathrm{H}_{5} \mathrm{O}_{7} ; 25 \mathrm{NaCl} ; 10 \text { glucose }\end{array}$ & 12.93 \\
\hline
\end{tabular}

Journal of Experimental Biology and Agriculture Science http://www.jebas.org 


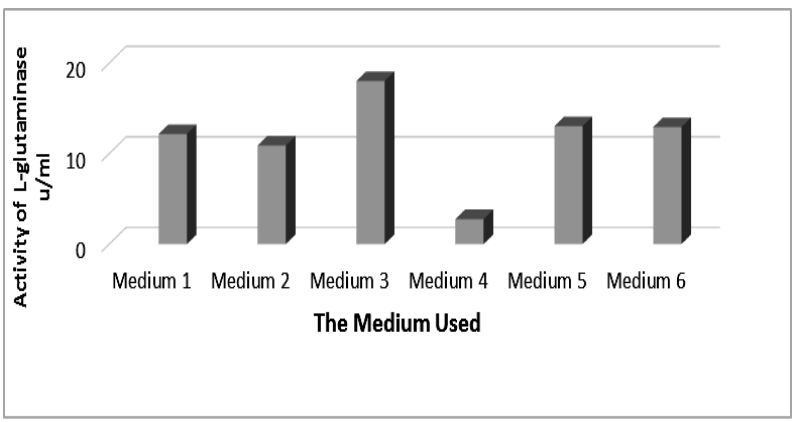

Figure 2 Effect of different media on L-glutaminase production by Streptomyces sp. D214

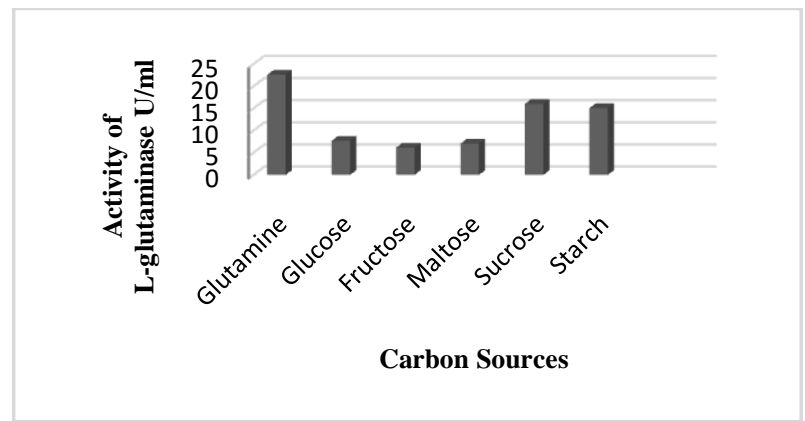

Figure 3 Effect of carbon sources on L-glutaminase production by Streptomyces sp. D214

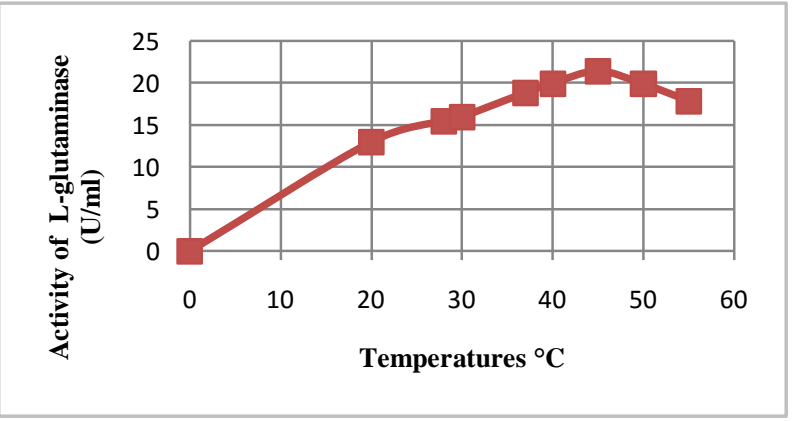

Figure 5 Effect of incubation temperature on L-glutaminase production by Streptomyces sp. D214

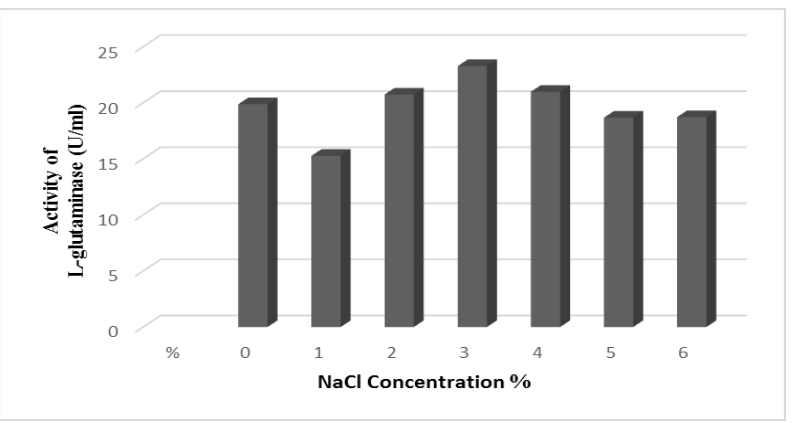

Figure 7 Effect of $\mathrm{NaCl}$ concentrations on L-glutaminase production by Streptomyces sp. D214
(Figure 3 and 4 ) and at incubation temperature $45^{\circ} \mathrm{C}$, initial $\mathrm{pH}$ value 7.0 and $3 \% \mathrm{NaCl}$ (Figure 5, 6 and 7), after five days of incubation (Figure 8).

\subsection{Antitumor's activity of isolated L-glutaminase}

Isolated L-glutaminase purified by column chromatography and antitumor's activity of the purified L-glutaminase was tested against the MCF-7 human breast carcinoma cell line. Result of study revealed that purified enzyme had excellent antitumor activity against the tumor cell line MCF-7 with $\mathrm{IC}_{50}$ of $10 \mu \mathrm{g} / \mathrm{ml}$.

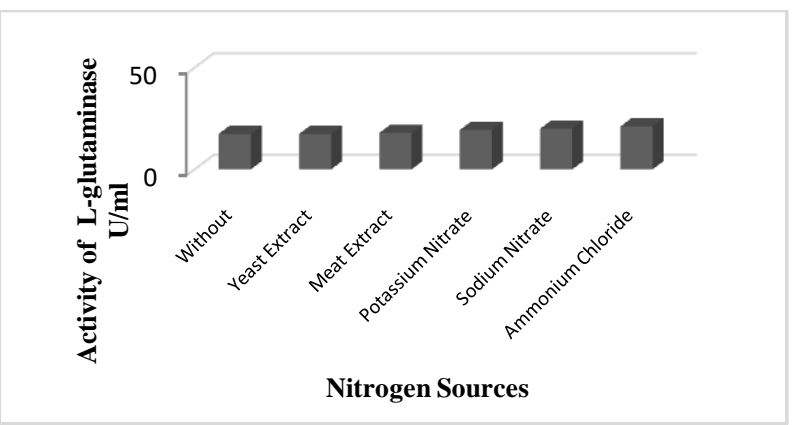

Figure 4 Effect of Nitrogen sources on L-glutaminase production by Streptomyces sp. D214

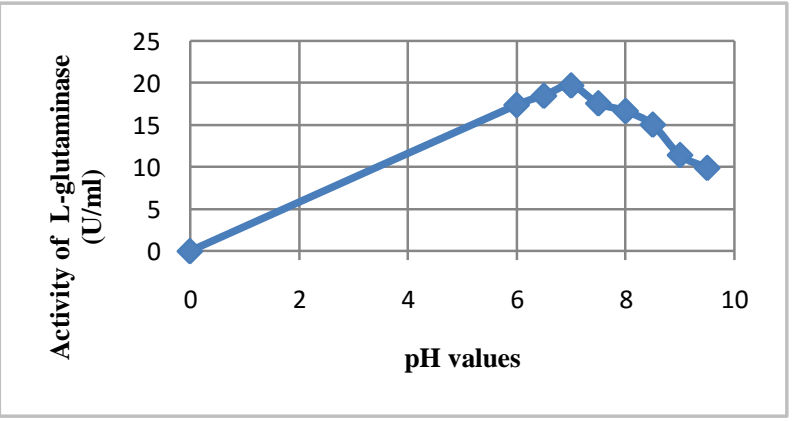

Figure 6 Effect of different $\mathrm{pH}$ values on L-glutaminase production by Streptomyces sp. D214

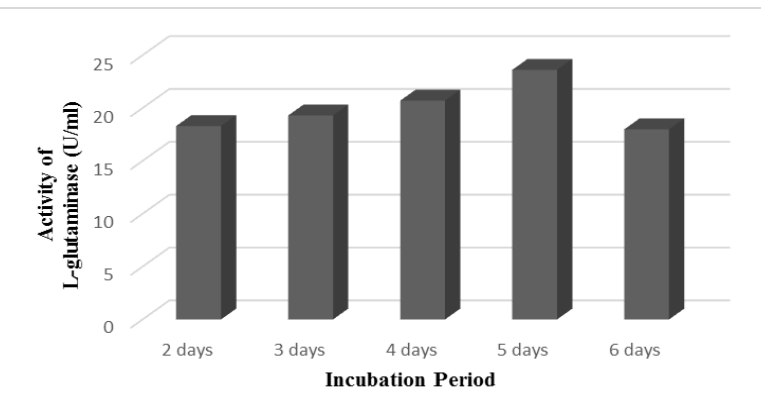

Figure 8 Effect of incubation period on L-glutaminase production by Streptomyces sp. D214

Journal of Experimental Biology and Agriculture Science http://www.jebas.org 


\section{Discussion}

L-glutaminase is a biosensor and a monitoring agent to determine glutamine level. It was produced by all living cells but bacteria have potential role for its industrial production. In recent years, interest in L-glutaminase production was increased due to its medical and industrial applications as antileukemia agent and taste enhancer in food (Kashyap et al., 2002; Nathiya et al., 2011).

Selective isolation of actinomycetes for L-glutaminase production is of great interest for preparing new antitumor agents. During this study, among the isolated 40 actinomycetes isolates, 10 isolates (40\%) were producing L-glutaminase at significant level and the most active isolate was RK9 which were identified using different techniques. Morphological and biochemical characters of the tested isolate RK9 were compared, with those of Streptomyces species given in the key of Nonomura and also with the species described in the Bergey's Manual of Determinative Bacteriology. The strain RK9 showed resembling characters to the genus Streptomyces. Similarly, L-glutaminase was obtained by Streptomyces avermitilis (Omura et al., 2001) and Streptomyces labedae (Han et al., 2012).

Lower percentage of L-glutaminase producers was obtained by Abdallah et al., (2012). These researchers isolated total 102 actinomycete isolates and among these only 6 Streptomyces isolates had L-glutaminase activities which was assayed by diameter of the pink zone ( $\mathrm{mm})$.

L-glutaminase producing isolates catalyzes the hydrolysis of Lglutamine to L- glutamic acid and ammonia which react with Nessler's reagent, producing deeper yellow color or brown precipitate. Determination of the released ammonia is an indirect indicator of L-glutaminase enzyme, produced by the tested bacterial isolates that giving positive result (Imada et al., 1973).

Effect of various physicochemical factors on L- glutaminase production by Streptomyces species was also detected and reported that under the best growth conditions, rapid Lglutaminase production was occurred (Robinson et al., 2001). The results of this study revealed that growth in medium 3 containing glutamine and ammonium chloride enhanced L-glutaminase production. From the obtained results, it can be conclude that $45^{\circ} \mathrm{C}$ was the optimum temperature for maximum L-glutaminase production while the results of Nathiya et al. (2011) suggested maximum enzyme production at $30-40^{\circ} \mathrm{C}$. At high temperatures, only few proteins which are essential for growth, may synthesize (Gawande \& Kamat, 1999). Maximum L-glutaminase from Trichoderma koningii was found at $33^{\circ} \mathrm{C}$ (El-Sayed, 2009) and with prolonged incubation, enzyme activity decreased sharply. On the other hand, in present study maximum L-glutaminase activity was obtained at pH7 while Abdallah et al. (2012) reported maximum activity at $\mathrm{pH} 8$ and no synthesis was detected at $\mathrm{pH} 3$, 4 and 11. In contrast to results of this study, Nathiya et al. (2011) reported higher glutaminase production by Aspergillus flavus at acidic $\mathrm{pH} 4.0$ while this activity decreased upto $50 \%$ at natural $\mathrm{pH} 7$.

MCF-7 is a breast cancer cell line isolated in 1970 from a 69-yearold woman and L-glutaminase showed a significantly inhibitory agent against the previous cell line with $\mathrm{IC}_{50}$ of $10 \mu \mathrm{g} / \mathrm{ml}$. Similarly, L-glutaminase was active against the tumor cell line, such as, Hep-G2 cells ( $\mathrm{IC}_{50}, 6.8 \mu \mathrm{g} / \mathrm{ml}$ ), HeLa cells ( $\mathrm{IC}_{50}, 8.3$ $\mu \mathrm{g} / \mathrm{ml}), \mathrm{HCT}-116$ cells $\left(\mathrm{IC}_{50}, 64.7 \mu \mathrm{g} / \mathrm{ml}\right)$ and RAW 264.7 cells $\left(\mathrm{IC}_{50}, 59.3 \mu \mathrm{g} / \mathrm{ml}\right)$, while the growth of MCF-7 cells was not effected (Reda, 2015).

In conclusion, L-glutaminase from Streptomyces was produced, purified and characterized. The purified enzyme showed antitumor activities against the tested cell line.

\section{Acknowledgment}

Authors thankfully acknowledges King Abdulaziz city for science and technology (KACST) for supporting this study.

\section{Conflict of Interest}

Authors would hereby like to declare that there is no conflict of interests that could possibly arise.

\section{References}

Abdallah NA, Amer SK, Habeeb MK (2012) Screening of LGlutaminase produced by actinomycetes isolated from different soils in Egypt. International Journal of ChemTech Research 4: 1451-1460.

Abdallah NA, Amer SK, Habeeb MK (2013) Production, purification and characterization of L-glutaminase enzyme from Streptomyces avermitilis. African Journal of Microbiology Research 7: 1184-1190.

Balagurunathan R, Radhakrishnan M, Somasundaram ST (2010) L-glutaminase producing actinomycetesfrom marine sedimentsselective isolation, semi quantitative assay and characterization of potential strain. Australian Journal of Basic and Applied Sciences 4: 698-705.

Balagurunathan R, Subramanian A (1993) Studies On marine Streptomyces nigrifaciens (P-9). I. Taxonomy and standardization of antibiotic production. Ciencias Marinas 19: 435-443.

Dubey R, Paul A, Prity N (2015) Isolation, production and screening of anti-cancer enzyme L-glutaminase from Bacillus 
subtilis. International Journal of Pharma and Bio Sciences 5: 96105.

Dura MA, Flores M, Toldrá F (2002) Purification and characterization of a glutaminase from Debaryomyces spp. International journal of Food Microbiology 76: 117-126.

El-Sayed AS (2009) L-glutaminase production by Trichoderma koningii under solid state fermentation. Indian journal of Microbiology 49: 243-250.

Gawande PV, Kamat MY (1999) Production of Aspergillus xylanase by lignocellulosic waste fermentation and its application. Journal of Applied Microbiology 87: 511-519.

Hall V, O’Neill GL, Magee JT, Duerden BL (1999) Development of amplified 16S ribosomal DNA restriction analysis for identification of Actinomyces species and comparison with pyrolysis-mass spectrometry and conventional biochemical tests. Journal of Clinical Microbiology 37: 2255-2261.

Han JH, Cho MH, Kim SB (2012) Ribosomal and protein coding gene based multigene phylogeny on the family Streptomycetaceae. Systematic and Applied Microbiology 35:1-6.

Imada A, Igarasi S, Nakahama K, Isono M (1973) Asparaginase and glutaminase activities of microrganisms. Journal of General Microbiology 76: 85-99.

Kashyap P, Sabu A, Pandey A, Szakacs G, Soccol CR (2002) Extra-cellular L-glutaminase production by Zygosaccharomyces rouxii under solid-state fermentation. Process Biochemistry 38 : 307-312.

Keerthi TR, Suresh, PV, Sabu A, Rajeevkumar S, Chandrasekaran M (1999) Extracellular production of L-glutaminase by alkalophilic Beauveria bassiana BTMF S10 isolated from marine sediment. World Journal of microbiology and Biotechnology 15: 751-752.

Krishnakumar S, Rajan RA, Ravikumar S (2011) Extracellular production of L-Glutaminase by marine alkalophilic Streptomyces sp.-SBU1 isolated from Cape Comorin coast, Indian Journal of Geo-Marine Sciences 40: 717-721.

Kumar SR, Chandrasekaran M (2003) Continuous production of L-glutaminase by an immobilized marine Pseudomonas sp. BTMS-51 in a packed bed reactor. Process Biochemistry, 38: 1431-1436.

Kumar V, Bharti A, Gusain O, Bisht GS (2010) An improved method for isolation of genomic DNA from filamentous actinomycetes. Journal of Engineering and Technology Management 2: 10-13.
Nakadai T, Nasuno S (1989) Use of glutaminase for soy sauce made by Koji or a preparation of proteases from Aspergillus oryzae. Journal of Fermentation and Bioengineering 67: 158-162.

Nandakumar R, Yoshimune K, Wakayama M, Moriguchi M (2003) Microbial glutaminase: biochemistry, molecular approaches and applications in the food industry. Journal of Molecular Catalysis B: Enzymatic 23:87-100.

Nathiya K, Nath SS, Angayakanni J, Palaniswamy M (2011) Optimised production of L-glutaminase: A tumor inhibitor from Aspergillus flavus cultures on agroindustrial residues. African Journal of Biotechnology 10: 13887- 13894.

Nonomura H (1974) Key for classification and identification of 458 species of the streptomycetes included in ISP. Journal of Fermentation Technology 52: 78- 92.

Okami Y (1986). Marine microorganisms as a source of bioactive agents. Microbiology Ecology 12: 65-78.

Ōmura S, Ikeda H, Ishikawa J, Hanamoto A, Takahashi C, Shinose M, Takahashi Y, Horikawa H, Nakazawa H, Osonoe T, Kikuchi H (2001) Genome sequence of an industrial microorganism Streptomyces avermitilis: deducing the ability of producing secondary metabolites. Proceedings of the National Academy of Sciences 98: 12215-12220.

Prabhu GN, Chandrasekaran M (1997) Impact of process parameters on L-glutaminase production by marine Vibrio costicola in solid state fermentation using polystyrene as an inert support. Process Biochemistry 32: 285-289.

Reda FM (2015) Kinetic properties of Streptomyces canarius Lglutaminase and its anticancer efficiency. Brazilian Journal of Microbiology 46: 957-968.

Renu S, Chandrasekaran M (1992) Extracellular L-glutaminase production by marine bacteria. Biotechnology Letters 14: 471474.

Robinson TP, Aboaba OO, Kaloti A, Ocio MJ, Baranyi J, Mackey BM (2001) The effect of inoculum size on the lag phase of Listeria monocytogenes. International journal of food microbiology 70: 163-173.

Sato I, Kobayashi H, Hanya Y, Abe K, Murakami S, Scorzetti G, Fell JW (1999) Cryptococcus nodaensis sp. nov., a yeast isolated from soil in Japan that produce a salt-tolerant and thermostable glutaminase. Journal of Industrial Microbiology and Biotechnology 22: 127-132. 
Wade HE, Robinson HK, Phillips BW (1971) Asparaginase and glutaminase activities of bacteria. Journal of General Microbiology 69:299-231.

Wakayama M, Yamagata T, Kamemura A, Bootim N, Yano S, Tachiki T, Yoshimune K, Moriguchi M (2005) Characterization of salt-tolerant glutaminase from Stenotrophomonas maltophilia
NYW-81 and its application in Japanese soy sauce fermentation. Journal of Industrial Microbiology and Biotechnology 32: $383-390$.

Williams ST, Sharpe ME, Molt JC (1989) In: Williams and Wilkins (Eds), Bergey's Mannual of Systematic Bacteriology 4: 2300-2648. 